17.

\title{
GRAD KAO MJESTO OBLIKOVANJA INTELEKTUALCA: KERUBIN ŠEGVIĆ I SPLIT
}

\section{Filip Šimetin Šegvić i Nikolina Šimetin Šegvić}

UDK: 32-05Šegvić, K.

Izvorni znanstveni članak

Sažetak: U bogatstvu nijansi međuratnih splitskih kulturnih i intelektualnih krugova uočava se poveznica s baštinom propale Austro-Ugarske Monarhije. Usprkos političkom usponu Splita, kao novog upravnog središta Dalmacije nakon 1918. godine, kontinuitet s razdobljem prijelaza stoljeća (oko 1900. godine) primjetan je upravo u sferi intelektualnog života. Kerubin Šegvić spada u one ličnosti splitskog znanstvenog, političkog i javnog života koji je svojim djelovanjem nastojao povezati sfere političkog, intelektualnog i kulturnog, otvarajući ali i sam stvarajući kontroverzne probleme. Kao javna angažirana osoba, Šegvić se isticao u različitim splitskim krugovima kao bliski suradnik don Frane Bulića, istaknuti pravaš i književnik te novinski kritičar, a i kasnije urednik. Istovremeno je njegova ličnost bila predmet kritika, a ponekad i rugla, upravo u rodnom Splitu, a brojni su istaknuti intelektualci ulazili s njime u žestoke znanstvene i političke polemike (F. Galović, A. G. Matoš, M. Krleža, A. Cesarec itd.). Ovaj intelektualno-povijesni portret otkriva slojeve Šegvićeve ideologičnosti u političkim i znanstvenim istupima te naročito mijene, koje su ga, od njegovih pravaških početaka 1890-ih godina do pogibije 1945. godine, obilježile.

Ključne riječi: Kerubin Šegvić, intelektualac, Split, grad, polemike, kritika

\section{O PREPLETANJIMA INTELEKTUALNE POVIJESTI I POVIJESTI GRADA}

onceptualne inovacije u sferi intelektualne povijesti prikladne su produbljivanju problema koji se u ovom radu, ako ne u potpunosti onda barem djelomično, otvara. One su okrenute prema, u širem smislu shvaćenom, istraživanju „mentalnog alat-pribora“ (L. Febvre), „mentalne atmosfere“ (M. Bloch), dakle, prema mentalitetima koji označavaju različite senzibilitete, intelektualne aktivnosti usmjerene prema „čartiranju“ različitih intelektualnih kozmosa. ${ }^{1}$ Stefan Collini, britanski povjesničar, u knjizi Absent Minds na vrlo

1 André Burguière, The Annales School. An Intellectual History, Ithaca - London 2009., 225. 
uvjerljiv način opisuje kontekst razvoja intelektualaca u Velikoj Britaniji, njihovog djelovanja, javnih debata i rasprava u kojima sudjeluju, stvarajući vrlo jasnu sliku međusobnih odnosa i poveznica. Iako Collini želi napraviti odmak od teza prema kojima britanski intelektualci nisu prisutni u društvu i prolaze svojevrsni poseban razvoj u usporedbi na kontinentalnu Europu, itekako ostaje svjestan specifičnog konteksta Velike Britanije i njezinoga razvojnog puta u 20. stoljeću, te naročito „engleštine“ koja obilježava, prema Colliniju, otočke intelektualce. ${ }^{2} \mathrm{~K}$ tome, iz praktičnih razloga - Collini teži široko stežućoj sintezi - izostavlja specifični kontekst ambijenta, sredine i porijekla intelektualaca koji i u britanskom slučaju ima važnu ulogu. U određenim se sredinama Velike Britanije tijekom 20. stoljeća profiliraju različite dominantne teme. Viktorijanski London, primjerice, nameće sam po sebi određene diskurse o društvu, politici, Imperiju, ljudskim pravima, odnosu prema kolonijama, što ih intelektualci prihvaćaju na različite načine. ${ }^{3} \mathrm{Ti}$ su načini često usko povezani s njihovim porijeklom ili životnim putovima: njihovi velški, škotski, karipski i drugi korijeni usmjeruju ih prema određenom kompleksu pitanja, oblikuju njihov odnos prema političkoj tradiciji zemlje, prema kulturi i društvu. Collinijev rad upozorava, s jedne strane, na opće kategorije sukladne sada već s brojnim kategorizacijama tipova intelektualaca, ali, $s$ druge strane, ocrtava i elemente jednog Sonderwega što ga uvjetuju društvene i političke prakse i tradicije.

Grad kao važna odrednica intelektualnih elita krajem 19. stoljeća i početkom 20. stoljeća, prodiranjem modernosti poprima prošireni značaj u javnom diskursu, nudeći pregršt novih načina kako intelektualci komuniciraju ne samo sa širom javnosti, već i međusobno. ${ }^{4} \mathrm{Za}$ sada je to najbolje prikazano kroz književnost. Tema intelektualca velika je tema u književnosti, pa tako i u hrvatskoj. I upravo se u periodu 19. i 20. stoljeća sjajno prati lik intelektualca, njegov razvoj, okolnosti, sudbina, a jedan od važnih elemenata koji uvelike utječe na to oblikovanje upravo je grad, što je prikazao i Krešimir Nemec u svom djelu Citanje grada. ${ }^{5}$ Nove teme koje se otvaraju upravo posredstvom intelektualne djelatnosti gradskih elita prelaze uže granice struke i postaju otvorenije prema javnim raspravama, pa već krajem 19. stoljeća rasprave o kulturi, umjetnosti, književnosti, arhitekturi, glazbi itd. postaju važnim komponentama javnog života. Budući da u kontekstu modernog grada s kraja 19. i početka 20. stoljeća te teme ne znače tek puku intelektualnu debatu, već utječu izravno na život građana, na taj način postaju dijelom svakodnevice i zaokupljaju širu publiku. ${ }^{6}$

Suvremena intelektualna povijest često se ocrtava i pomoću mikrokozmosa ideja pojedinih intelektualaca, mikrokozmosa koji se stvaraju od makrokozmosa prošlih ili suvremenih

\footnotetext{
Stefan Collini, Absent Minds. Intellectuals in Britain, Oxford 2006.

F. W. Maitland, Township and Borough, Cambridge 1898., 18-24.

4 O tome vidi naročito: Friedrich Lenger - Klaus Tenfelde (ur.), Die europäische Stadt im 20. Jahrhundert. Wahrnehmung - Entwicklung - Erosion, Köln - Weimar - Wien 2006.

5 Krešimir Nemec, Čitanje grada. Urbano iskustvo u hrvatskoj književnosti, Zagreb 2010. Vidi i: Zvonko Kovač, „Tumačenje i prikazivanje intelektualaca-umjetnika danas", Intelektualac danas. Zbornik radova s međunarodnog skupa Desničini susreti 2013. (ur. Drago Roksandić i Ivana Cvijović Javorina), Zagreb 2014., 107-121.

6 Taj međuodnos gradskih elita i ,novih tema“ koje ulaze u sferu svakodnevnog vrlo jasno ocrtava primjerice: Iskra Iveljoć, Očevi i sinovi. Privredna elita Zagreba u drugoj polovici 19. stoljeća, Zagreb 2007.
} 
mislioca, odnosno iz reakcija, kritika, novih pristupa starim idejama. Povjesničari upozoravaju i na jednu bitnu komponentu intelektualne povijesti - mentalitete, koji za razliku od tradicionalnijeg praćenja novog, usmjeravaju na praćenje ograničenosti ljudskog uma unutar jednog vremena. $\mathrm{Na}$ taj način povjesničar prodire u nesvjesno, otkriva osjećaje, navike, mentalne rituale - bez kojih ne bi bila jasno vidljiva povijest društvenih promjena. Štoviše, moguća je komparativna analiza mentaliteta i ideja - čak i mentaliteta i ideologija, posebice pod pretpostavkom da se radi o različitim, ali ne potpuno suprotnim mislenim kategorijama koje se manifestiraju kod intelektualnih elita, odnosno narodnih masa - kojom u mnogočemu dolazimo do objašnjenja i vidnih društvenih kontrasta, radikalizacije društva, kulture nasilja itd.

\section{Kerubin ŠegVić i Split}

Matej Marin Šegvić rodio se 23. veljače 1867. u splitskom predjelu Lučac. Budući da nije potjecao iz bogate obitelji, a da je $\mathrm{k}$ tome njegova majka oboljela još dok je pohađao osnovnu školu, ubrzo je Matej Šegvić završio u poznatom splitskom Zakloništu MartinisMarchi za djecu. ${ }^{7} \mathrm{U}$ tom je zavodu proveo tri godine života, ostavši pritom siroče. Nakon što se pridružio splitskim franjevcima u samostanu kod Poljuda u listopadu 1878., odlazi u Zadar gdje upisuje privatnu gimnaziju s nastavom na talijanskom jeziku. ${ }^{8} \mathrm{Od}$ tada započinje njegova dugotrajna povezanost $s$ talijanskim jezikom i kulturom: od ranih dana čita talijanske i klasične latinske pjesnike, prati zbivanja u talijanskoj književnosti, historiografiji, politici i kulturi općenito.? Još je za školovanja pristupio franjevačkom redu te je svoje svjetovno ime odmijenio duhovnim Cherubin, kako se otada nazivao i potpisivao. Maturirao je 1886. u Zadru, gdje se 1889. i zaredio, dok je novicijat prošao u Kopru, Trstu i Gorici. U Zadru završava i studij bogoslovlja 1890. godine. Potom postaje nastavnik u Kopru, zatim na Korčuli i Špiljarima kod Kotora. Godine 1889. postaje i član Matice hrvatske, za čije publikacije od tada redovno piše. Od 1895. godine u Zagrebu upisuje klasičnu filologiju i slavistiku na Filozofskom fakultetu. ${ }^{10}$ Nakon desetak godina franjevačke službe, napustio je 1898. godine red, ali je ostao svjetovnim (biskupskim) svećenikom te

O tome vidi: Danica Božıć-BužAnčıć, „Ivan Petar Marchi-Markić: njegovo djelovanje i njegova oporuka“, Radovi Zavoda za povijesne znanosti HAZU u Zadru, 41/1999., 181-202; Stanko Piplović, „Fundacije i zgrade obitelji Martinis Marchi u Splitu“, Grada i prilozi za povijest Dalmacije, 24/2012., 333-368.

8 Bare Poparić, „Povodom sedamdesetgodišnjice života Kerubina Šegvića“, Hrvatska smotra, 5/1937., br. 2 , 104.

9 Božidar Petrač, „Svestranost i neujednačenost opusa Kerubina Šegvića“, u: Kerubin ŠEgvić, Aporije književnosti $i$ povijesti, Zagreb 2013., 24-25. Kerubin Šegvić će i na području proučavanja talijanskog jezika i kulture ostaviti traga. I taj bi doprinos ubuduće trebalo ozbiljnije analizirati i valorizirati. Osim što je komunicirao s brojnim talijanskim književnicima i povjesničarima (napose Giovannijem Papinijem), što je zajedno s prijateljem Vinkom Lozovinom nastojao uspostaviti društvo prijatelja talijanske knjige, Šegvić je objavio i nekoliko djela vezanih uz talijanski jezik i kulturu: K[erubin] Š[Egvić], Talijansko trgovačko dopisivanje - Corrispondenza commerciale italiana, Zagreb [s.a.]; Kerubin ŠEgvić, Vodič kroz Rim i okolicu, Zagreb 1925.; Kerubin ŠEgvić, Gramatika talijanskog jezika u dvadeset $i$ pet lekcija sa praktičnim dodatkom, Zagreb [1927.]; drugo izdanje: Zagreb 1941.

10 B. Poparić, „Povodom sedamdesetgodišnjice života Kerubina Šegvića“, 104-105; Živan Bezić, „Don Kerubin Šegvić. Život, smrt i djelo (I.)“, Hrvatska obzorja, 4/1996., br. 1, 81-88. 


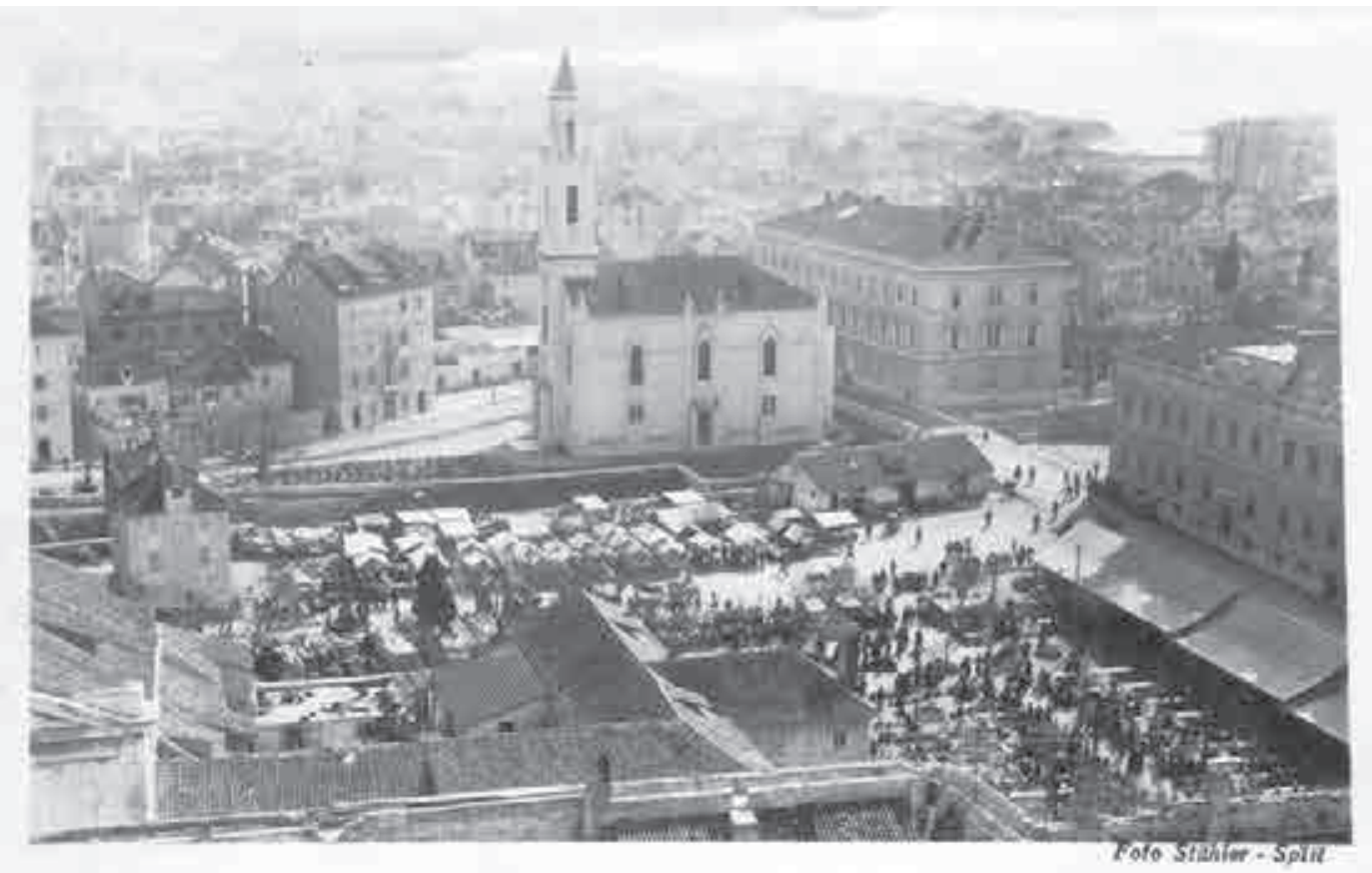

Sl. 1. Župna crkva sv. Petra u središtu splitskog gradskog predjela Lučac, jedno od žarišta okupljanja protutalijanskog, hrvatskog nacionalnog naboja. Kerubin Šegvić rodio se u tom predjelu Splita, u glavnoj ulici Radunici, blizu rodnih kuća Ante Trumbića i Marina Kuzmića. Radi se o težačkom splitskom predjelu koji je u ranom novom vijeku bio često izložen pustošenjima i osmanskim provalama. Čitavo predgrađe i crkva teško su nastradali u bombardiranju Splita 1944. godine.

se od tada potpisivao kao don Kerubin Šegvić. Od 1898. do 1900. godine Šegvić studira i arheologiju u Beču (gdje ga se vodi i kao Matthäus Šegvić). Poseban dojam na njega ostavljaju predavanja Emila Reischa, koji je netom bio preuzeo mjesto redovnog profesora klasične arheologije i držao predavanja o grčkoj kulturi. ${ }^{11}$ Potom radi u Kotoru u državnoj gimnaziji kao suplent, predavajući latinski, grčki, talijanski i „srpsko-hrvatski“. Radi i u učeničkoj knjižnici, nautičkoj i trgovačkoj školi te kao konzervator Središnje komisije za istraživanje i očuvanje građevnih spomenika. ${ }^{12}$ Tijekom rada u gimnaziji Šegvić ne zapušta književno-kritički rad, već i dalje objavljujuje različite komentare, prijevode i kritike hrvatskih i crnogorskih klasika.

Kerubin Šegvić je svojim intelektualnim djelovanjem, dugotrajnom političkom i novinarskom karijerom ostavio određen trag u Splitu. Ondje je, međutim, uvijek bio „u prolazu“, između životnih stanica: Zadra, Kotora, Šolte i Zagreba. Iako je obrazovanje stekao prvenstveno u Zadru, a naročito nakon 1918. češće boravio prvo u Zagrebu, potom kraće Osijeku i dulje na Šolti, Šegvić je ostajao povezan sa svojim rodnim gradom. U njegovim

\footnotetext{
11 B. Poparić, „Povodom sedamdesetgodišnjice života Kerubina Šegvića“, 106.

12 Mitteilungen der K.K. Zentral-Kommission für Erforschung und Erhaltung Kunst- und Historischen Denkmale, Wien 1904.; Ž. Bezıć, „Don Kerubin Šegvić“, 83.
} 
političkim istupima, kao i u njegovim stručno-znanstvenim radovima, jasno se ističe briga za dalmatinsku kulturu i prošlost. Šegvić se otvoreno zalaže za brojna druga otvorena pitanja koja su se ticala povijesne baštine i kulture. Još je u travnju 1919. na redovnom sastanku Privremenog narodnog predstavništva zahtijevao rješavanje pitanja povrata različitih vrijednosti dalmatinskih crkvenih i državnih riznica koje su pod izgovorom zaštite imovine prebačene u Beč tijekom trajanja Prvog svjetskog rata ili su završile u Italiji. Pritom se također naročito zalagao za povrat arhivskog gradiva koje je pod uvjetima rata oduzeto iz Dubrovačkog arhiva. ${ }^{13}$ Ustrajao je na rješavanju toga pitanja pa je i javno, u novinama, pisao tekstove o važnosti tog „znanstveno historijskog blaga“, uključujući se u polemiku oko vraćanja u Dubrovnik dijela arhivskog gradiva koje je nakon Prvog svjetskog rata završilo u Beogradu. ${ }^{14}$

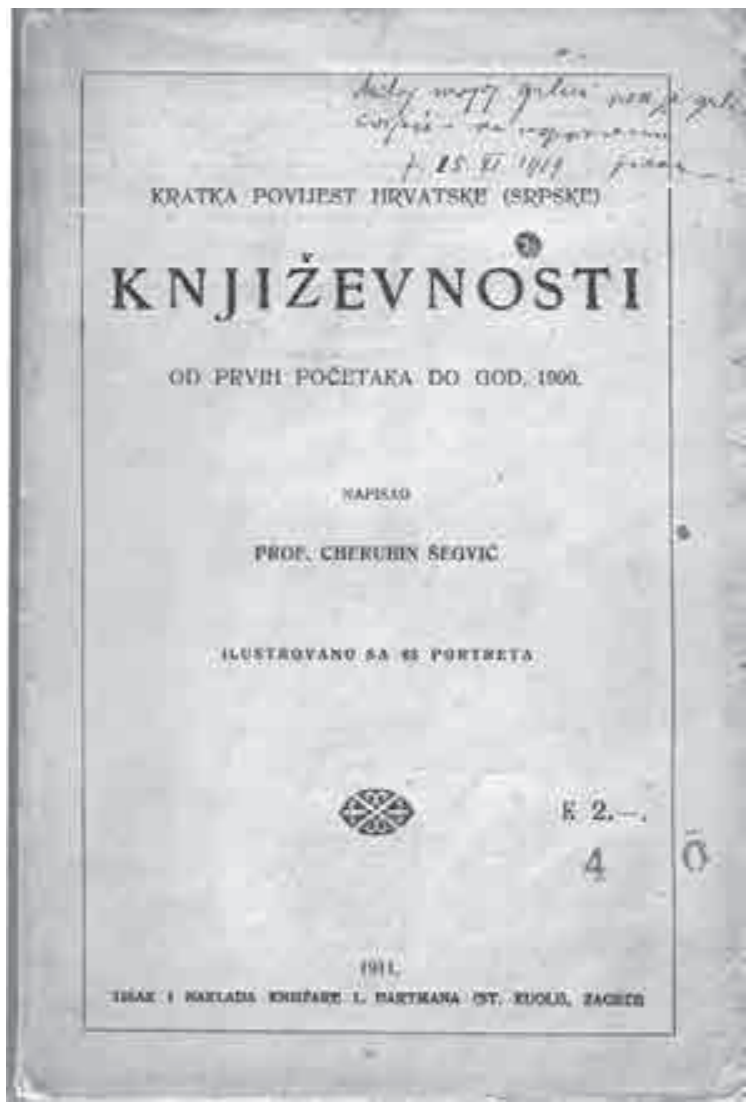

Sl. 2. Naslovnica Šegvićeve knjige objavljene u izdanju zagrebačkog Kuglija (1911.), izdavačke kuće s kojom Šegvić oko 1900. često surađuje, s njegovom posvetom

\section{ŠEGVIĆEV SPLITSKI KRUG}

Sa Splitom je Šegvić bio povezan i preko jednog od svojih uzora i patrona. Uz Prodana u Zadru i Kumičića u Zagrebu, u Splitu je to svakako bio don Frane Bulić, koji je kao stručnjak bio uživao velik ugled još prije Prvog svjetskog rata. Bulić je u Kerubinu Šegviću vidio mladog učenika voljnog znanja. Poticao je njegovo daljnje obrazovanje, usmjerujući ga upravo prema studiju arheologije u Beču. Prema Bari Popariću, Bulić je Šegviću sugerirao da napusti beletristiku i krene u ozbiljna znanstvena istraživanja na području arheologije i

13 Stenografske beleške Privremenog narodnog predstavništva Srba, Hrvata i Slovenaca: 14. redovni sastanak, Zagreb 1919., $283-285$.

14 Šegvić podsjeća i na bana Khuen-Héderváryja, odnosno „arhivsku aferu“, smatrajući smještanje dubrovačkog arhivskog gradiva u Beograd još gorim činom. K[erubin] Š[EGvić], „Borba za arhive u Hrvatskoj“, Hrvatski list (Osijek), br. 136, 17. 5. 1927., br. 136, 2. O pitanju gradiva iz Dubrovačkog arhiva koje je nakon Prvog svjetskog rata bilo u Beogradu vidi napose: Vesna Miović - Nikša Selmani, „Turska kancelarija i Acta Turcarum od vremena Dubrovačke Republike do danas“, Anali Dubrovnik, 45/2007., 235-284. 
povijesti jer je u njemu vidio i svog nasljednika na mjestu upravitelja Arheološkog muzeja u Splitu, iako do toga nikada nije došlo. ${ }^{15}$

Da je Bulić imao povjerenja u Šegvića, pokazuje i činjenica da pripada u relativno malen broj odabranih osoba koji su s don Franom surađivali na tekstovima i prijevodima u Bullettinu. Kao arheolog, Šegvić je i uz Josipa Bervaldija pomagao Buliću pri istraživanjima natpisa u Solinu. Sam je Bulić opisao u jednom kraćem članku kako su Šegvić i on u kolovozu 1898. došli u Solin čitati nad ruševinama Šegvićevu pripovijest Na solinskih ruševinah ${ }^{16}$ i to upravo na dan kada su otkriveni djelići nadgrobnog natpisa kraljice Jelene, koje su zajednički, s velikim oduševljenjem, skupljali i odnosili u Split kako bi ih sastavili. ${ }^{17}$ Kasnije će o natpisu kraljice Jelene sam Šegvić objaviti i članak kao suplement Bullettina. ${ }^{18}$ Tijekom boravka na Šolti, gdje je Šegvić bio župnik, također u arheološkim istraživanjima više puta surađuje s Bulićem i njegovim suradnikom Ljubom Karamanom kod Grohota, izvještavajući u novinama o otkrićima koja ocjenjuje važnim za povijest kulture u Dalmaciji, a u kojim je istraživanjima Šegvić desetljećima sudjelovao. ${ }^{19}$

No, Šegvić se u Splitu ipak nalazio, i u političkom i u stručnom smislu, tijekom većeg dijela karijere u Bulićevoj sjeni. Rugalačka kultura splitskog humora ubrzo je uočila fizičke razlike između Bulića i Kerubina Šegvića, ${ }^{20}$ koji je malešan, „suh“ i mršav, „mefistofelske vanjštine“, ${ }^{21}$ s naočalama i „ružne glave“ u Splitu predstavljao fizičku suprotnost Frani Buliću. ${ }^{22}$ Teško je reći je li zbog Splita Šegvić imao određen kompleks. Šegvić je ondje u nekoliko pokušaja bez uspjeha tražio zaposlenje. Osim novinarsko-uredničke djelatnosti, nije se uspio zaposliti niti u Arheološkom muzeju niti dugoročno u splitskim školama. $\mathrm{Na}$ Poljudu je u župi i školi bio tek kratkotrajno, 1897. - 1898., kao suplent. A nije dobio ni mjesto kanonika splitske stolne crkve za koje se natjecao. ${ }^{23}$ Unatoč potpori don Frane Bulića, na Šegvića se najčešće gledalo kao na Bulićevog pomoćnika, osobu u njegovoj prilično velikoj sjeni.

Unatoč svemu, Šegvić upravo u Splitu oko 1900. godine prolazi kroz jedan od najznačajnijih perioda vlastite znanstvene karijere. Surađuje s Tresićem-Pavičićem, koji će mu,

15 B. Poparić, „Povodom sedamdesetgodišnjice života Kerubina Šegvića“, 106.

16 Cherubin Šmgrić, Na solinskih rusevinah. Pripoviest iz staro-kršćanske dobe u Solinu, Zagreb [s.a.].

17 Frane Bulić, „Kako je nađen najvažniji natpis iz dobe kraljeva hrvatske krvi“, Mladost, 5/1925., br. 5, $133-136$.

18 Cherubino ŠEgvić, „Iscrizione sepolcrale di Elena, figlia di Tomislavo, regina croata“, Supplemento al 'Bullettino di archeologia e storia dalmata", 1902., br. 4-5, 1-21.

19 K[erubin] ŠEgvić, „Važna arheološko historijska otkrića na otoku Šolti“, Hrvatski list (Osijek), br. 141, 22. 5. 1927., 4.

20 Od nekolicine fizičkih opisa, ovdje je za izdvojiti: Bogdan Radica, Živjeti nedoživjeti, knj. 1: Uspomene hrvatskog intelektualca kroz moralnu i ideološku krizu Zapada, München - Barcelona 1982., 76-77; Nikola Rušınović, Moja sjećanja na Hrvatsku, Zagreb 1996., 114; te feljton Ive Mihovilovića „Izmišljeni kralj Tomislav II.“, Večernji list (Zagreb), br. 3002, 14. 4. 1969., 19. Šegvića su razni kolumnisti u polemikama i kritikama, još od Matoša, često napadali i na toj razini. Tako primjerice u Javnosti, nastojeći izrugivati Šegvićevu gotsku tezu objavljenu u Njemačkoj, piše: „I kakvu bi tek senzaciju Šegvićeva rasprava bila izazvala, da je ilustrovana Šegvićevom fotografijom, pa da su u Nemačkoj mogli i zorno da vide, kako izgleda taj zaista neslovenski egzemplar 'gotskog Hrvata!'“ „K. Šegvić kao 'gotski Hrvat'", Javnost, 2/1936., br. 34., 787.

21 DAZG 849, osobni fond Ivan Peršić, „Fanatici i realisti, kompromisanti i ekstremisti u hrvatskoj politici najsudbonosnijih trideset godina od $1914 / 15$ do $1944 / 45^{\prime \prime}$, kutija 1.

22 Bogdan Radica, Sredozemni povratak, München - Barcelona 1971., 279-280; Isti, Živjeti nedoživjeti, knj. 1, $76-77$.

23 K. Š́tgvić, Aporije književnosti i povijesti (prir. Božidar Petrač), Zagreb 2013, 26-27. 
unatoč sukobima, ostati blizak veći dio života, prijateljuje sa slikarom Celestinom Medovićem, povjesničarom Barom Poparićem itd. Osim spomenutih arheoloških otkrića na terenu, Šegvić sam piše suplemente Bulićevom Bullettinu, objavljuje u Vjesniku Kr. državnog arbiva $u$ Zagrebu, prevodi tekst arheologa Roberta Schneidera o Dioklecijanovoj palači na talijanski, objavljuje značajne radove u inozemnim časopisima i započinje istraživanja koja će dugi niz godina provoditi. Iako su Šegvićevi vlastiti radovi o povijesnim temama bili polemički i ispolitizirani te je znanstvenost ostala često na drugom mjestu (arheologija mu je u mnogim slučajevima, naročito u kasnijim periodima djelovanja, služila samo kao potpora u dokazivanju glavnih teza), ipak treba istaknuti da upravo njegova arheološka istraživanja, nastala u suradnji s Bulićem i Bervaldijem, čine studiozne i znanstvene radove. No, i ti su radovi zbog istraživanih tema smatranima kontorverznima, često uzburkavali vrlo zahtjevnu splitsku čitateljsku publiku. Sigurno je i da je Franu Bulića izra-

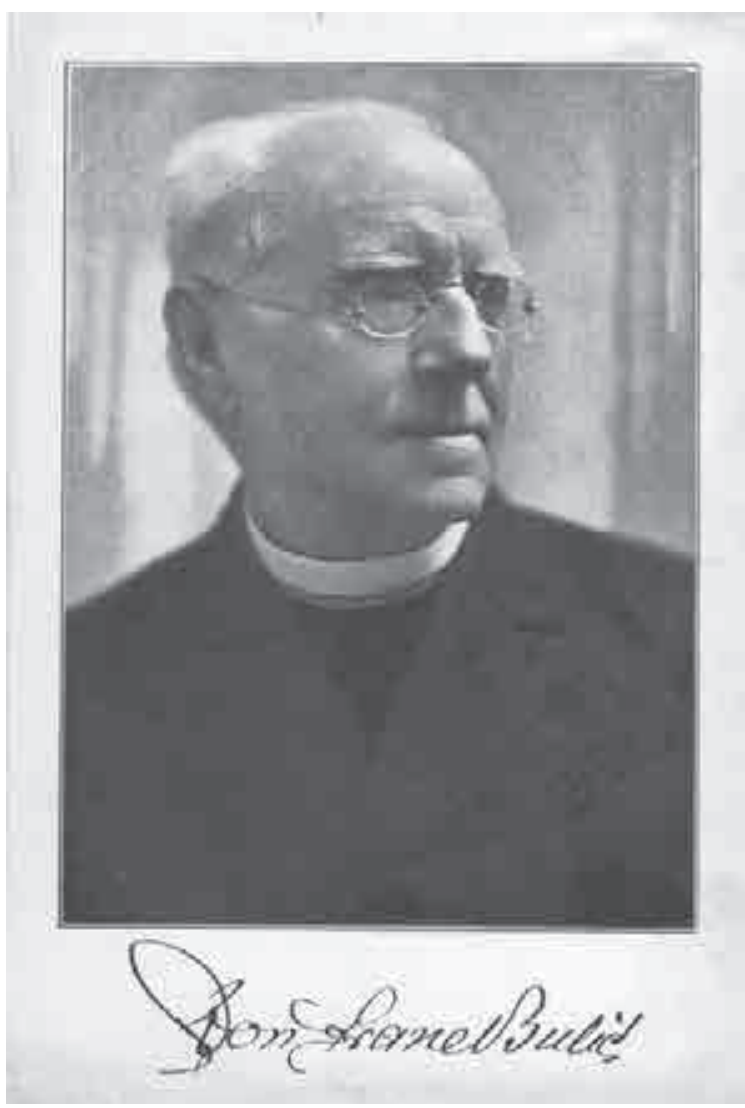

Sl. 3. Don Frane Bulić, Šegvićev učitelj i najbliži suradnik. Portret iz međuratnog razdoblja (korišten poslije u akcijama sakupljanja donacija za Bulićev spomenik i zbornik, u čemu sudjeluje i K. Šegvić). zito cijenio, što se vidi i iz članaka koje je posvetio Bulićevom radu i djelovanju prigodom raznih obljetnica. U jednom takvom tekstu Šegvić ističe muke oko (splitskog) ambijenta i okoline koje su don Franu snašle, govoreći iz prve ruke, kao Bulićev suradnik. ${ }^{24}$ U godini Bulićeve smrti (1934.), Šegvić u svojoj Hrvatskoj smotri objavljuje opsežan nekrolog. Ondje se s velikim poštovanjem i divljenjem osvrće na rad i djelovanje Frane Bulića te na njegov značaj za hrvatsku arheologiju i znanost općenito. ${ }^{25}$ Pišući o Buliću, Šegvić se dotiče ponovno Splita, smatrajući upravo Bulićevu ulogu ključnom za određeni procvat grada:

Dovoljno je spomenuti, da je njegov [odn. Bulićev, op. aut.] rad učinio od Splita i Solina atrakcionom točkom za kulturne ljude zapada. Nitko ne dolazi u Split da se najede njegovih smokava ili sočnoga grožđa, niti da se okupa na plitkoj pješčanoj plaži „Bačvica“ nego dolaze u Split, da gledaju ostatke Dioklecijanove palače, da gledaju solinske ruševine, da

24 Kerubin ŠEgvić, „Učenjački jubilej don Frana Bulića“, Hrvatsko kolo, 1908., knj. 4, 426-431.

25 K[erubin] ŠEgvić, „Don Frane Bulić“, Hrvatska smotra, 2/1934., br. 8-9, 299-314. 
vide one stare poganske i kršćanske grobove, da vide one otkopane bazilike, one grobove svetih Mučenika u Manastirinama; da čuju, kako magična riječ Bulićeva ono sve oživljuje, slika jedro i uvjerljivo. ${ }^{26}$

\section{Kerubin ŠEgVić Kao istraživač Splita i Dalmacije}

Još jedan važan aspekt Šegvićeve povezanosti sa Splitom je i njegov stručno-znanstveni rad. Iako je svoja djela najčešće pisao u Zagrebu (te na Šolti), a stručnu afirmaciju postigao u Zadru, Kotoru te prije svega u Zagrebu, ipak su odabir tema i opći interesi najčešće bili usmjereni na Dalmaciju i njegov rodni Split. Kao povjesničar i arheolog veći je dio svog interesa posvetio povijesti Dalmacije, a njegovi su se stavovi, teze i rasprave često odražavale na njegovu popularnost, odnosno nepopularnost u Splitu. Osim gotske teorije, o kojoj će još biti riječi, na prvom mjestu dolazi rasprava o životu sv. Dujma, koja se negativno odrazila na Šegvića i njegov ugled u Splitu. ${ }^{27}$ Naime, Frane Bulić, Josip Bervaldi i Šegvić našli su se na istoj strani u debati koja je nastala početkom 20. stoljeća oko sv. Dujma: službeni i tradicionalni stav splitske crkve nalagao je tumačenje prema kojemu je Dujam živio u 2. stoljeću, u Trajanovo vrijeme. Taj stav osiguravao je izravnu povezanost Salonitanske crkve $s$ apostolskom tradicijom i sv. Petrom. Na temelju dugoročnih epigrafskih analiza nalaza, Bulić, Bervaldi i Šegvić su se tom tradicionalnom mišljenju suprotstavili, iznijevši tezu o tome kako je Dujam bio mučen u vrijeme Dioklecijana, 304. godine. ${ }^{28}$ Upravo je Šegvićev doprinos debati, suplement Bullettinu pod nazivom Storia e leggenda di S. Domnione o Doimo vescovo martire di Salona e delle sue reliquie. Saggio storico-critico iz 1901., zaustavljen u tiskari i zabranjen prema nalogu Kongregacije obreda u Rimu, prema kojemu se trebalo smiriti već razbuktanu polemiku. Splitski kler oštro je napadao Bulića, a leđa su mu okrenuli i neki poznanici, poput don Luke Jelića. ${ }^{29}$ Frane Bulić je Šegvićeve separate po zabrani sam pokupio i sačuvao, ${ }^{30}$ a sukob internacionalizirao te naposljetku i uz posredstvo Vatikana pobjedonosno okončao spor. ${ }^{31}$ Bulićevom internacionalizacijom problema veliki interes za temom javio se i u inozemstvu, što je Šegviću otvorilo prostora da o problemu salonitanskih i splitskih biskupa i nadbiskupa piše u uglednom časopisu Analecta Bollandiana. ${ }^{32}$

\footnotetext{
$\overline{26}$ Isto, 302; K. Š Egvić, Aporije, 27.

27 B. Poparić, „Povodom sedamdesetgodišnjice života Kerubina Šegvića“, 106.

28 Josip Dukić, „Istraživanje i objavljivanje salonitanskih kršćanskih natpisa“, Tusculum, 2/2009., br. 2, 181.

29 Frane Bulić, Izabrani spisi, Split 1984., 39.

30 Također vidi i drugi Šegvićev rad: Cherubin ŠEgvić, „Chronologie des Évęques de Salone suivie de la Chronologie des Archevêques de Spalato“, Analecta Bollandiana, sv. 33, 1914., 265-274. „Don Frane Bulić i sv. Domnio (Dujam)“, Solinska kronika (Solin), br. 185, 15. 2. 2010., 19.

31 F. Bulić, Izabrani spisi, 39.

32 Ch. ŠEgvić, „Chronologie des Eveques de Salone“, 265-274.
} 


\section{INTERES I ZA LOKALNA POLITIČKA PITANJA}

Okušao se Kerubin Šegvić u nekoliko navrata u Splitu i kao urednik i suradnik različitih novina, časopisa i drugih listova. Otkako je Tresić-Pavičićev Novi viek pokrenut 1897. godine u Splitu, Šegvić u njemu piše različite priloge. Međutim, najznačajnija epizoda za Šegvićev životopis njegovo je sudjelovanje u pokretanju Hrvatske riječi: glasila dalmatinskih Hrvata 1924. godine. Na poziv nekolicine političara, Šegvić se unatoč prijetnjama u „orjunaškim listovima“, prihvatio redakture tog lista kako bi „navijestio rat“ režimu i „onom društvenom talogu, koji se bješe, od sloma Austrije, sakupio u Splitu da mu denaturira hrvatsko lice i slomi osjećaje“. ${ }^{33}$ Naime, Šegvić je već 1922. godine fizički napadnut u Splitu nakon jednog govora u Beogradu u Narodnoj skupštini; taj napad je sam tumačio kao dio „demokratsko-orjunaškog terora“ koji se sprovodio nad Hrvatima. Od tada sudjeluje u Hrvatskom Borcu i drugim listovima, žestoko napadajući državnu vlast, tvrdeći da ona taj teror omogućuje, a na vlastitom primjeru dokazujući da policija ne pruža potrebnu zaštitu. ${ }^{34}$ Stoga se naposljetku odlučio pokrenuti i vlastiti list koji bi borbenim opozicijskim stavom pozivao na otpor takvim praksama. List će izlaziti pod Šegvićem vrlo kratko, ali će on kao glavni urednik ostvariti važne kontakte s predstavnicima splitske inteligencije, napose mlađom generacijom: Bogdanom Radicom, ${ }^{35}$ Miljenkom Bukaricom itd. Iako je redakturu Hrvatske riječi ubrzo prepustio drugima, Šegvić je i sam nastavio pisati članke za te novine te je naposljetku u Zagrebu uhićen i prebačen u istražni zatvor u Splitu, gdje je osuđen na zatvorsku kaznu. ${ }^{36}$

\section{HISTORIOGRAFSKA DJELATNOST: OKUPLJANJE SVIH INTELEKTUALNIH STAVOVA}

Iako je Šegvićeva historiografska djelatnost dobro poznata, još nije opširnije i u cijelosti obrađena. Obilježena je uglavnom radovima s područja srednjovjekovne povijesti Dalmacije te hrvatske povijesti 19. stoljeća. Svoju karijeru kao povjesničar započeo je komentarima i nadopunama na teze starijih hrvatskih povjesničara, poput Natka Nodila i Ferde Šišića. ${ }^{37}$ Pisao je i bavio se političkim, vjerskim, kulturnim i socijalnim pitanjima iz navedenih područja. Najkontroverznija su njegova istraživanja na području etnogeneze Hrvata,

33 K. ŠEgviĆ, „Na prvu godišnjicu“, Hrvatski list (Osijek), br. 4, 9. 1. 1926., 2.

34 Usp. „Kaznena rasprava protiv Joe Matošića, glavnog urednika 'Hrvatskog borca', pisca jednog članka prof. Kerubina Šegvića i odgovornog urednika Bogdana Kralja“, Hrvatski borac, 1/1922., br. 14, 2; K. ŠEgvić, Aporije, 58-62.

35 Radica se u svojim tekstovima i kasnije objavljenim zbirkama eseja i knjigama češće referirao na Kerubina Šegvića, obično pozitivno. Ovako je Šegvića ukratko opisao: „S Don Kerubinom sam surađivao u splitskoj Hrvatskoj riječí. Često sam k njemu išao na Šoltu, gdje je imao lijepu vilu. Bio je živa enciklopedija, imao je ogromno znanje, napose iz hrvatske stare i suvremene povijesti. Jedan put smo čak išli čamcem veslajući do Marulićeva Nečujma; za cijelo vrijeme on je recitirao Marulićeve, Hektorovićeve i Lucićeve stihove. Bio je zaljubljenik Hrvatske." Bogdan RaDICA, Hrvatska 1945, München - Barcelona 1974., 206.

37 Vidi: Kerubin ŠEgvić, „Kralj Koloman i Hrvati g. 1102. Jedna političko-historička rasprava prof. Ferde Šišića“, $H r-$ vatska (Zagreb), br. 247, 20. 10. 1907., 2; Isti, Vjera Vidova ili religija Srba i Hrvata, Split 1899. Kasnije piše i kratak članak o samome Nodilu: „Ličnost prof. Natka Nodila“, Hrvatska straža (Zagreb), br. 39, 16. 2. 1939., 2. 


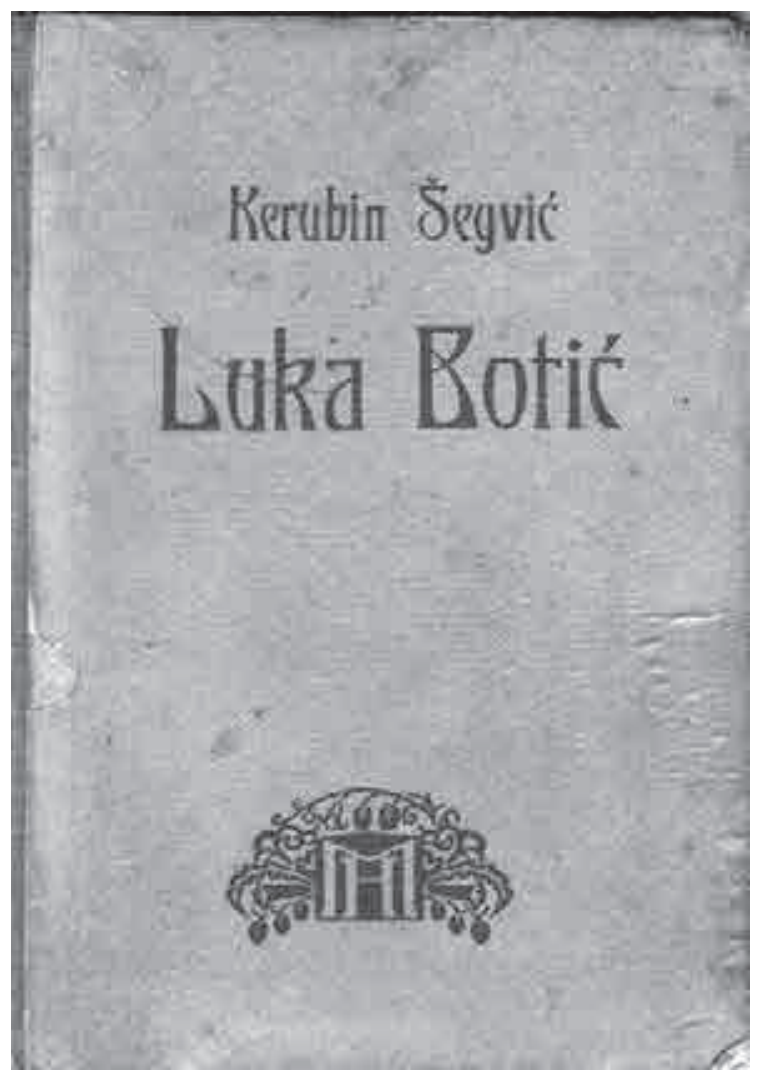

Sl. 4. Naslovnica Šegvićeve biografske studije o Luki Botiću u izdanju Matice hrvatske (1930.)

koja je tijekom vremena postupno mijenjao i revidirao. Treba posebno izdvojiti i Šegvićevu sklonost pisanja biografija, od kojih su pojedine istovremeno znanstvene i publicističke. Biografija je za Šegvića pogodan agens prenošenja poduka iz povijesti, odnosno žanr pomoću kojega ističe herojske osobe hrvatske povijesti. Tako Šegvić piše knjige i članke o sv. Jeronimu, Tomi Arhiđakonu, Anti Starčeviću, Eugenu Kvaterniku, Luki Botiću, Grgi Martiću, Marku Maruliću, Ivi Prodanu i drugima. Do Starčevića i Kvaternika došao je kao dalmatinski pravaš, na istraživanje Tomine kronike potaknuo ga je Frane Bulić, ali i svećenička naobrazba kod franjevačkih i isusovačkih profesora. ${ }^{38}$ Njegove su biografije tipičan primjer amaterske historiografije 19. stoljeća, podijeljene između znanstvenosti, erudicije, romantizma i publicističkoknjiževničkih naginjanja. U njima se često može pronaći i širi kontekst vremena: najčešće je to u okviru povijesti Splita, kako je slučaj s biografijom Tome Arhiđakona i Luke Botića. U knjizi o Botiću je tako nekoliko stranica posvećeno strukturama društva u Splitu, talijanskim i hrvatskim utjecajima, odnosu stanovnika prema zaleđu i otocima te drugim karakteristikama Splita 19. stoljeća. ${ }^{39}$ Šegvić o Splitu krajem 19. stoljeća piše kako bi „vjerno“" opisao „splitsku atmosferu“, slijedeći i vlastita zapažanja iz rane mladosti. ${ }^{40}$ Tako će, opisujući položaj i život težaka u Splitu, evocirati i vlastita sjećanja iz djetinjstva sa svojom majkom, ističući podijeljenost na hrvatski i talijanski grad. ${ }^{41}$ Taj je Šegvićev pristup zapažen. Krunoslav Bego, odvjetnik i publicist koji se sam bavio poviješću Splita, u pismu Šegviću tako hvali njegove biografske radove o Preradoviću, Tomi Arhiđakonu i Luki Botiću, ističući kako upravo u knjizi o Botiću zabilježena sjećanja na Split 19. stoljeća imaju vrijednost, zaključujući da je Šegviću „naša gradska prošlost poznata kao malo komu“.42

\footnotetext{
38 Kerubin ŠEgvić, Toma Splićanin. Državnik i pisac 1200.-1268., Zagreb 1927. Vidi također: B. Poparić, „Povodom sedamdesetgodišnjice života Kerubina Šegvića“, 106-108.

39 Kerubin ŠEGvić, Luka Botić. Njegov život i njegova djela, Zagreb 1930., 13-26.

40 Isto, 10.

41 Isto, 25.

42 NSK, R-7982, B-b, 5-6, Pismo Krunoslava Bege Kerubinu Šegviću od 31. 12. 1931. Bego u pismu Šegviću sugerira i pisanje biografije Jerolima Kavanjina kao važnog splitskog baroknog pjesnika.
} 
Također, Šegvić u svojim djelima teži detaljnije obraditi kulturnu povijest. Dakako, radi se o kulturnoj povijesti najtradicionalnijeg oblika, dakle, kako ju je shvaćala historiografija 19. stoljeća prije Burckhardta, čija je zapravo svrha pokazati razvijenost jednog naroda, kod Šegvića Hrvata, iznoseći primjere visoke kulture. Već 1909./1910. godine Šegvić tako u sklopu niza večernjih pučkih predavanja drži u Zagrebu seriju predavanja naslovljenu „Počeci kulture u Hrvata“ $i$ „Kultura u Hrvata“. ${ }^{43}$ Kulturna i politička djelatnost izuzetno su povezane i u skoro svim Šegvićevim biografskim knjigama i člancima, od Ante Starčevića, Eugena Kumičića sve do Petra Zrinskog. Kultura je za njega bila sredstvo kojime se povijest širila među narodom, kojime je dobivala na dojmu i moći među običnim ljudima. ${ }^{44}$ Šegvićevo shvaćanje povijesti, a naročito kulturne povijesti, također je usko vezano za književnost. Radi se o tradicionalnom shvaćanju historiografije kao literarne grane. Bilo da se radi o društvenoj i kulturnoj povijesti Splita, Šolte, Boke kotorske ili nekog drugog predjela, najčešće je upravo Dalmacija u Šegvićevom fokusu. Izuzetno interesantan je tako između ostaloga i kratak prikaz povijesti Dalmatinske zagore, koji Šegvić radi upravo uz pomoć književnosti, zaključujući da „[a]ko nemamo na znanstvenom polju iscrpive knjige, imademo na književnom“. ${ }^{45}$ Ipak, Šegvićevo shvaćanje kulturne povijesti, kakvo je javno iznio u jednom svojem eseju, pokazuje itekako da je Šegvić pratio modernije pristupe u historiografiji, da je znao primijeniti pristupe $s$ kojima se na bečkim seminarima upoznao te da je o kulturnoj povijesti Hrvatske razmišljao šire i suvremenije negoli to njegovi radovi daju naslutiti. Radi se o njegovom eseju „Jedna velika književna potreba“ iz 1909. godine, kojime nastoji potaknuti sveobuhvatan projekt sastavljanja hrvatske kulturne povijesti koja bi potom bila temelj hrvatskoj enciklopediji. ${ }^{46}$ Šegvić poziva na suradnju Akademije i Matice hrvatske kao vodećih institucija, koje bi pod pokroviteljstvom vlade trebale okupiti skupinu stručnjaka koji bi zajednički radili na projektu. ${ }^{47}$ Sam u eseju predlaže i podjelu te kulturne povijesti na tri dijela: na „djela ljudskog uma“ (pod čime Šegvić podrazumijeva vjeru, umjetnost i filozofiju), „djela ljudskog udruženja“ (obitelj i država) i na „djela ljudskog materijalnog rada“" (poljodjelstvo, obrt i trgovina), upućujući pritom i na temeljne radove ranijih istraživača koji su doprinijeli nekim od spomenutih grana te široke kulturne povijesti, između ostalih one Franje Markovića, Natka Nodila, Ivana Kukuljevića Sakcinskog i dr. ${ }^{48}$

Naobrazba koju Šegvić stječe u Zadru, Zagrebu i kasnije u Beču, tradicionalna je. Često se oslanja i citira strane autore, od kojih najbolje poznaje one talijanske (npr. Furija Lenzija ili izdanja Antonija Muratorija), nešto slabije francuske (npr. Françoisa Migneta, Charlesa Diehla ili Alfreda Nicolasa Rambauda) te njemačke i austrijske (npr. Ernsta

43 „Oeffentliche Vorträge“, Agramer Zeitung (Zagreb), br. 277, 3. 12. 1909., 5; „Volkstümlicher Vortrag“, Agramer Zeitung (Zagreb), br. 15, 20. 1. 1910., 6.

${ }^{4}$ Ch. ŠEgvić, „Život i djela Evgenija Kumičića“, u: Eugen Kumıčıć, Jelkin bosiljak. Pripoviest iz istarskoga života, Zagreb 1905., LIXI.

45 Cherubin ŠEGvić, „Dalmatinsko Zagorje u lijepoj knjizi“, Glas Matice hrvatske, 2/1907., br. 5-6, 33-36.

46 Kerubin Š EGvić, „Jedna velika književna potreba“, Glas Matice hrvatske, 4/1909., br. 18-20, 142-145. Prema: K. ŠEGVIĆ, Aporije, 211-223.

47 K. ŠEGVIĆ, Aporije, 222-223.

48 Isto, 213-214. 
Wilhelma Förstemanna, Luda Moritza Hartmanna ili Reta Heinzela). Po znanstvenoj kritičnosti i analizi, kao i stilu, Šegvić ipak vidno zaostaje za prvacima hrvatske historiografije toga vremena, kao što su Vjekoslav Klaić ili Ferdo Šišić. Moguće je zaključiti da su mu u određenoj mjeri, po strukturi teksta, načinu iznošenja argumentacije i stilu historiografski uzori bili Natko Nodilo i Frane Bulić. No, Šegvićevi su tekstovi često popularno-publicistički, tendenciozni, odnosno prilagođeni određenoj političkoj ideji. Svoja istraživanja često ishitreno objavljuje ili zastupa iako nisu provedena do kraja, a u prikupljanjima vrela i dokumenata nedostaje mu sustavnosti. Slično kao i Bulić, Šegvić se ne boji kontroverza ili zastupanja stavova koji idu protivno dominantnoj struji, ali ga težnja da popularizira određene znanstvene teme, često gura u ishitrene i neutemeljene tvrdnje koje su kod ozbiljnih kritičara izazivale negativne reakcije i manjak razumijevanja. Takve tendencije bi zasjenile cjelinu djela. Dovode to do toga da su, naročito u njegovim kratkim novinskim člancima, zaključci nerijetko ishitreni, odnosno da tijekom vremena vehementno zastupa u tekstovima suprotne stavove, pobijajući svoja ranija. $S$ druge strane, njegova je školovanost i znanje u istim djelima izlazila na vidjelo. Jasno je to upravo iz Šegvićevih polemika, primjerice iz rasprave koja se 1920 -ih vodila oko dvije važne isprave splitskih benediktinki (čiju je vjerodostojnost osporavao Viktor Novak) i ocjene Šegvićevog odgovora koju daje Stjepan Gunjača. On o tome piše: „Šegvić se oborio na Novaka s jakom primjesom političke prizme, s glavnim motivom da obrani napadnutu čast splitskih srednjovjekovnih koludrica, no uz to je ipak zatresao i čvrstoćom Novakove historiotopografske argumentacije. “49 Pojedina njegova djela otvaraju u hrvatskoj historiografiji nove teme i često predstavljaju inicijalnu točku kasnijim znanstvenim istraživanjima.

\section{SPlitsKa „PRESUdA“ Kerubinu ŠEgViću}

Šegvić očito pri koncipiranju gotske teorije nije slijedio vlastite riječi, jer je u jednom polemičkom tekstu o Stjepanu Radiću upozoravao: „Tko živi od prošlosti i u prošlosti, kao moja malenkost, onda ga dira svaka povreda prošlosti, makar ona došla od prijatelja, makar ona bila izrečena u najplemenitije i najrodoljubnije svrhe. Prošlost se ne smije nakazati nikakvom politikom. Ona mora sijati pred nama u sjaju istine. “50 Šegvićeva je reputacija u Splitu, i prije negoli je identificiran s gotskom tezom, bila izričito dvojako obilježena. U krugovima političke elite grada Šegvić vjerojatno nije slovio naročito dobro. Često je radikalno mijenjao stavove o pojedincima, što se negativno odražavalo na njegov ugled: ambivalentan odnos prema Tresiću-Pavičiću zadržao je do kraja života, Radića je i vehementno napadao i branio, slično i Trumbića, kojeg je prije 1918. godine žestoko kritizirao da bi mu se kasnije kao suradnik priklonio. Zamjeralo mu se što je pred kraj Prvog svjetskog rata napustio Dalmaciju, a njegova polemička narav dovela ga je u neprijateljstvo s obitelji Gri-

\footnotetext{
49 Stjepan Gunjača, Ispravci i dopune starijoj hrvatskoj historiji, sv. 1: Izvori, Zagreb 1973., 377.

50 Kerubin Š́gvić, „Između dviju obala“, Hrvatski list (Osijek), br. 196, 27. 8. 1926., 2.
} 
sogono, kao i s brojnim drugim uglednicima tog vremena. Njegovo je političko djelovanje, izvan užeg kruga Bulića i Trumbića, često negativno vrednovano. Zbog toga je preferirao mirnoću Šolte ili širi pak Zagreb, pa je dugo vremena živio na relaciji Zagreb - Split; u Split je volio ponekad tek nakratko svratiti, čuti što ima novoga i sastati se u kavani „Muljačicic sa svojim prijateljima i poznanicima, raspraviti nove teme iz politike i kulture. ${ }^{51} \mathrm{U}$ međuratno su vrijeme splitske kavane bile sastajalište političke i intelektualne elite; osim kavane „Central“ i tzv. „Stola mudraca“ istaknutih građana predvođenog gradonačelnikom Ivom Tartagliom, različite kavane su povezivane s različitim političkim opcijama - Enzo Bettiza tako se prisjetio kavane „Muljačić“, koja je okupljala „Hrvate“, dok su u kavanu „Nanni“ dolazili „talijanaši“, a kod Delića „monarhisti“.52 Radica će Šegvićev odnos prema Splitu ukratko razjasniti:

Iako je Kerubin Šegvić vrlo često bio strancem u Splitu i nije se osjećao u njemu kod kuće, on je bitno bio izražaj splitskog nemira, splitske proturječnosti, splitskog unutrašnjeg antagonizma, koga ima u najvećoj mjeri i u Varošu i na Lučcu. ${ }^{53}$

Iako nije boravio trajno u gradu, ipak je Šegvić pratio promjene u Splitu. Da se angažirano zanimao za urbanistički razvoj Splita svjedoči, primjerice, pismo iz 1927. koje je uputio kao prigovor na stanje splitske gradske luke gradonačelniku Ivi Tartagliji, kritizirajući i prakse carine i opći arhitektonski dojam. Tartaglia odgovara Šegviću da ono što kritizira pripada u djelokrug Općine, ali također na kraju pisma naglašava:

Ti gledaš inače na stvari vrlo crnim naočalima. Nema dvojbe da se u Splitu učinilo koješta što ne odgovara arhitektonskim tradicijama i ambijentu našega grada, ali ovo je neminovna posljedica povećanog lučkog i željezničkog robnog i osobnog prometa u luci. Luka je malena, a potrebe rastu, pak one traže i razne žrtve (...). ${ }^{54}$

Shvaćajući ambivalentnost Splita oko 1900. godine i u međuratnom vremenu, sam je Šegvić radio brojne razdiobe grada na dijelove, razlike između, po Frani Buliću, „Splićana i Spalatrina". ${ }^{55}$ Uviđao je podjele na moćne patricije i obične težake, ${ }^{56} \mathrm{kakvim}$ se sam smatrao, ipak se ne osjećajući istovremeno blizak tim težačko-radničkim krugovima iz kojih je njegova obitelj potjecala, već žudeći za afirmacijom u krugu intelektualne elite Splita. Težio je pripadati „mediteranskoj rasici“ - kako je sam nazivao tip mediteranskog čovjeka odraženom u velikim povijesnim ličnostima Dalmacije, ali u splitskom okruženju često

51 NSK, R-7982, B-b, 51-57, Iz pisma Vinka Lozovine Kerubinu Šegviću od 19. 9. 1940.

52 Saša Ljubičıć, „Bettize nisu napustili Split zbog partizana“, Slobodna Dalmacija (Split), 24. 11. 2004. (http://arhiv. slobodnadalmacija.hr/20041124/temedana01.asp). Usp. Zdravka Jelaska Marijan, Grad i ljudi: Split 1918.-1941., Zagreb 2009., bilj. 1609. O splitskim kavanama vidi također str. 365-366.

53 B. Radica, Sredozemni pouratak, 279.

54 NSK, R-7982, B-b, 113, pismo Ive Tartaglije Kerubinu Šegviću od 11. 4. 1927.

55 K. ŠEGVIĆ, „Don Frane Bulić“, 307.

56 Usporedbe radi, Ivan Kovačić slikovito piše o tri dijela Splita: „(...) u Splitu [je] bilo dva dila težakov, a treći dil gospode, grajani, artišti, jer Split je tad [početkom 20. stoljeća, op. a.] bi ka jedno veliko težasko misto". Ivan Kovačić, Smij i suze starega Splita, Pennsylvania 1970., 79. Vidi također: Tomislav BranĐolica, „Društvena raslojavanja u međuratnom Splitu: jedna povijest odozdo“, Vladan Desnica i Split 1920. - 1945. Zbornik radova sa znanstvenog skupa Desničini susreti 2014. (ur. Drago Roksandić i Ivana Cvijović Javorina), Zagreb 2015., 27-40. 


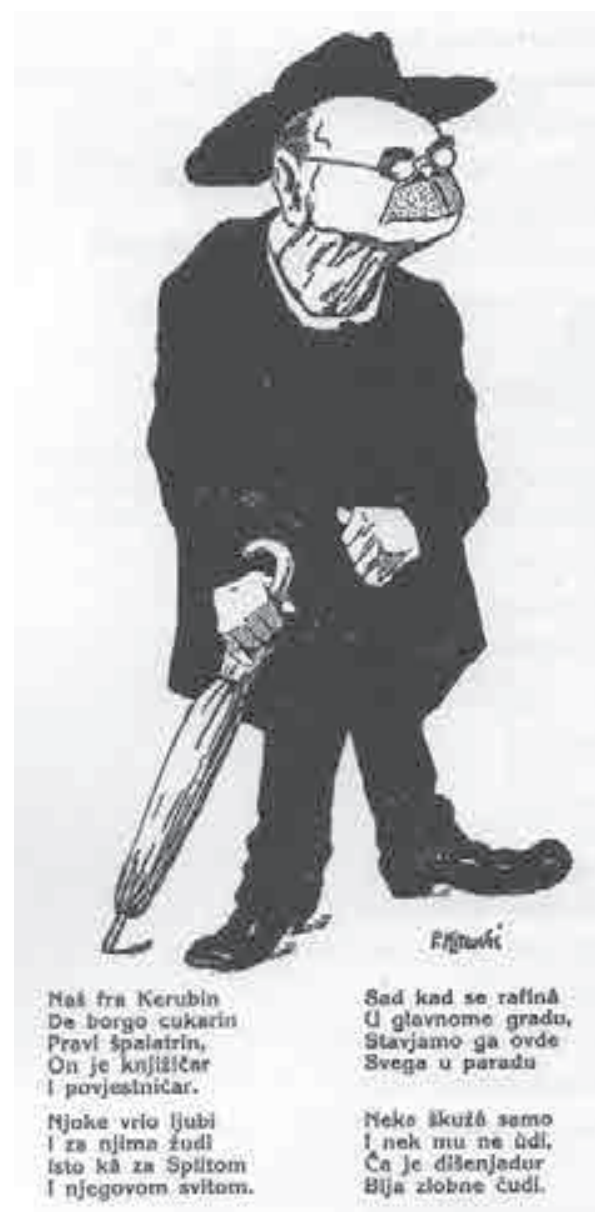

Sl. 5. Karikatura Kerubina Šegvića objavljena 1911. godine u Duji Balavcu

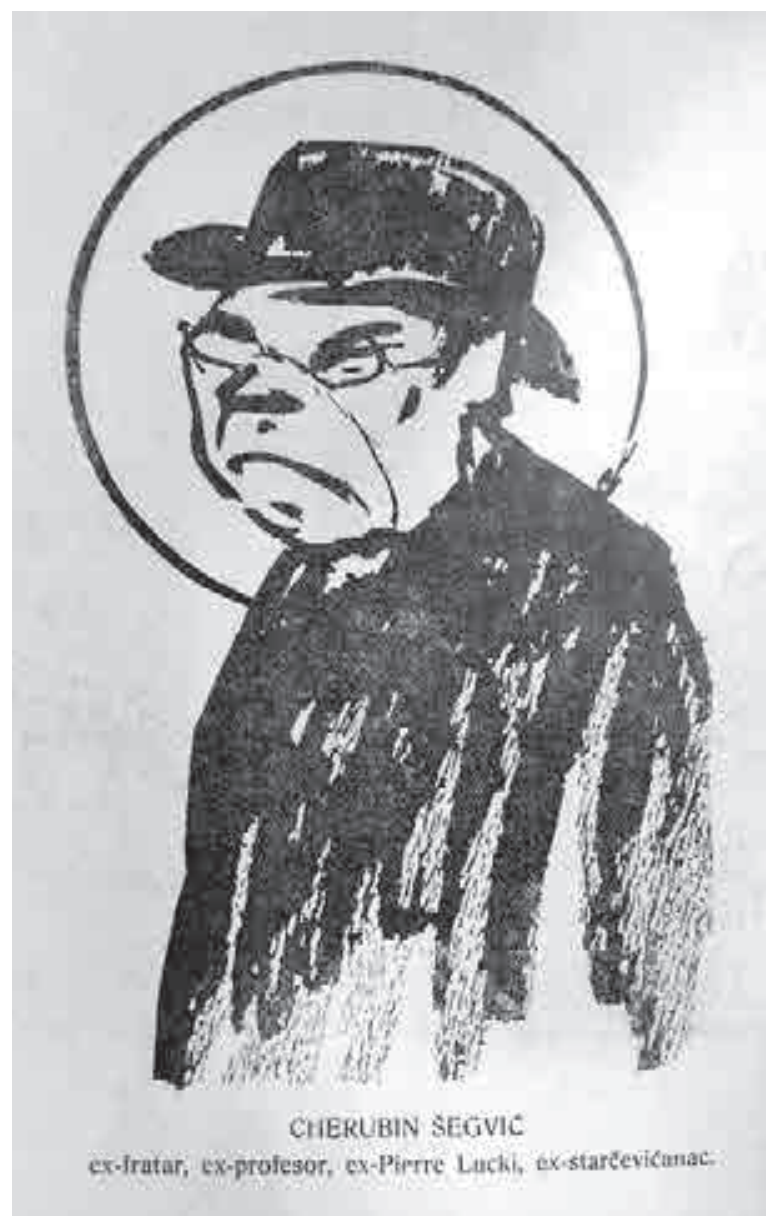

Sl. 6. Karikatura Kerubina Šegvića objavljena 1936. godine u Hrvatskoj smotri

nije tako percipiran. ${ }^{57}$ Poznati splitski humoristički mjesečnik Duje Balavac 1911. baš je Šegvića prikazao na karikaturi u podrubrici „iz Zagreba“ rugajući mu se kao „špalatrinu“ koji je u Zagrebu, ${ }^{58}$ dok je Hrvatska smotra Zvonimira Vukelića govorila o „ex-fratar, exprofesor, ex-Pierre Lucki, ex-starčevićanac“ želeći negativno naglasiti njegovu svestranost kao prevrtljivost. ${ }^{59}$

Dvojnost koja obilježava Šegvića tijekom čitave karijere, za B. Radicu je usko vezana uz Split, splitski i mediteranski mentalitet. On je Šegvića opisao ovim riječima:

Taj Split - koji se tako jetko označio u Kerubinu Šegvić, polemičaru protuslovnom i gorkome, koji je mogao od Starčevićeva pravaštva preuzeti čak i aktivnu ulogu kod stvaranja „vlaške“ Jugoslavije, pa čak i savjetovati Matu Drinkovića i svoje ostale prijatelje kako da

\footnotetext{
7 B. RadicA, Sredozemni povratak, 76-78.

58 „Iz Zagreba“, Duje Balavac, 1911., serija II, br. 9, 6.

59 „Karikature“, Hrvatska smotra, 4/1936., br. 33, 23.
} 
surađuju s Aleksandrom, i da u isti mah, samo malo kasnije, bude i ideologom ustaštva i gotskog podrijetla Hrvata - nije nikada zaboravio na Tomu Arhiđakona, koji je bio više učiteljem Trumbića, nego li jednog od svojih tumača, Šegvića. Jer u Kerubinu Šegviću ima mnogo od splitskog pučanskog značaja, nikada zadovoljnoga, uvijek spremnog na otpor, na pobunu, pozdravljajući sada u oduševljenju jedno uvjerenje, a poslije oprečno onome prvome. Da li je to sve iz oportunizma ili iz organskog splitskog nezadovoljstva, koje iz oduševljenja za Slavenstvom prima širokim zanosom Srpstvo, da se odmah malo zatim okrene svom svojom snagom i impulzivnim temperamentom protiv Srpstva u naručaj Hrvatstva i Zagreba, smatrajući se čak vođom jedne revolucionarne politike, Hrvatstva. Šegvićev značaj najbolje označuje taj multipolaritet Splita: njegovo skakanje iz jednog ekstrema u drugi, slavenski negativno i mediteranski neukrotivo. ${ }^{60}$

Pred kraj svojeg života Šegvić je očito osjećao potrebu ostaviti Splitu - rodnom gradu - nešto trajno. Tako oko 1939. godine piše Dušanu Mangeru, voditelju Gradske biblioteke, da namjerava svoju zbirku knjiga, korespondenciju i jednu Medovićevu sliku ostaviti upravo knjižnici, ${ }^{61}$ kako bi se iskupio rodnom gradu. Šegvić, naime, kao razlog navodi dug prema Splitu, smatrajući da nije „ništa za njega uradio“, što očito pokazuje i koliko je Šegvić bio opterećen Splitom, neopravdano umanjujući svoj vlastiti doprinos:

(...) Ne mogu ti kazati, kako me silno boli, da i ja, Splićanin kao i ti, premda ti spadaš u najnoviji patricijat, a ja sam iz plebsa, nisam ničim zadužio svoj rodni grad, nisam ništa za njega uradio, što bi vrijedilo da se spomene. Valjda nisam tomu kriv ja, krive su prilike, koje su me natjerale na emigraciju iz najljepšeg kraja naše Domovine, ljepšeg nego je Italija, kako sam ponosno tvrdio 15. XI 1939. pred začudjenim Papinijem. Pošto sam potpuno uvjeren, da je isključena mogućnost da bi se ja ikada više mogao bilo čim odužiti mojemu Splitu, za kojim mi je uvijek čeznula i danas čezne nostalgijom napunjena duša, zato ti javljam ovo: (...) Već sam davno odlučio da svoje knjige, svoje rukopise, svoju korespodenciju ostavim Gradskoj biblioteci, kojoj si otac i vodja. Osim toga ostavljam joj i uljeni portrait, što mi ga je izradio nezaboravni prijatelj Celestin Medović u najvećem naponu svoje stvaralačke snage. To je sve, moj Dušane, što neosporno imadem svoga i čim smijem raspolagati. Mojoj nećakinji Olgi Mihovilović-Šusta, koja se velikom predanošću brine za mene i njeguje sinovskom ljubavlju, naredio sam, da tako raspoloži s mojim knjigama i sa portraitom.

Valjda ne bi bilo s gorega to provesti i prije smrti. No moje su knjige dosta u neredu. Mnogo ih je osakaćenih. Istrage i premetačine mnogo su toga uništile. Ali imade još mnogo toga, što će biti od koristi onima, koji se budu trudili ako dospiju oko proučavanja posljednjih 50-60 godina naše povijesti. Osobito korespodencija je obilata. Imadem i po koje pismo „Staroga“. Veliku korespodenciju s Bulićem itd....

Javi mi karticom, jer treba štediti, jesi li primio ovo pismo, pa ćemo do prigode ući detaljnije u provedbu, ako ti pristaneš na ovu moju sinovsku ponudu Splitu.

Primi sve najbolje želje za novu godinu od tvoga staroga

D. Kerubin Šegvića, Lučanina ${ }^{62}$

60 B. Radica, Sredozemni povratak, 279. Vidi također: B. Radica, Živjeti nedoživjeti, knj. 1, 38.

61 Na kraju do toga nije došlo, jer se Šegvićeva ostavština, nakon što je 1945. konfiscirana, nalazi pohranjena u Nacionalnoj i sveučilišnoj knjižnici u Zagrebu.

62 Citirano prema: Hrvoje Morović, Povijest biblioteka u gradu Splitu, sv. 1, Zagreb 1971., bilj. 10, $252-253$. 


\section{TRAGIČAN ZAVRŠETAK}

Nakon sloma NDH u svibnju 1945., Šegvić je u Zagrebu već u lipnju uhapšen te osuđen na smrt nakon brzog suđenja pred Vojnim sudom Komande grada. ${ }^{63}$ Za Šegvića su se, bez rezultata, zauzeli njegovi prijatelji i kolege Svetozar Rittig ${ }^{64}$ i đakovački biskup Antun Akšamović. I Alozije Stepinac je prosvjedovao na postupanje nove vlasti u Hrvatskoj te se posebice osvrnuo na Šegvićev slučaj riječima:

Iako je Maršal jasno izjavio, da će svećenicima, koji nisu okrvavili svoje ruke, nego su bili samo nerazboriti, biti oprošteno, starac od 79 godina, K. Šegvić, bijaše osuđen na smrt, iako nije naveden dokaz o njegovom zločinačkom ponašanju. On bijaše osuđen kao pristaša gotske teorije o porijeklu hrvatskog naroda. To je donekle bezumna znanstvena teorija, koja jedva može biti dokazana, i on bi mogao prije biti osuđen radi slaboumnosti. Prihvaćanje ove znanstvene teorije prema zdravom razumu ne opravdava osudu na smrt. Ne može se dokazati, da je profesor Šegvić poticao ljude na zločine na račun svoje teorije. ${ }^{65}$

U Vjesniku se 30. srpnja 1945. objavljuje članak „Inspiratore i izvršioce nečuvenih zločina nad našim narodom i njihove pomagače stigla je zaslužena kazna“. Ondje se spominje i Šegvić, koji je svojom gotskom teorijom poticao i raspirivao „nacionalnu mržnju naroda Jugoslavije" te time slabio njezin otpor pred agresijom fašizma. ${ }^{66}$

\section{UMJESTO ZAKLJUČKA: KULTURNi USPON MEĐURATNOG SPLITA}

„Multipolaritet“ o kojem Bogdan Radica govori u vezi sa Splitom i Kerubinom Šegvićem svjedoči i o bogatoj slojevitosti kulturnog, intelektualnog, ali i radničkog života grada. Od vremena oko 1900. godine pa tijekom međuraća Split kao grad raste i postaje sve značajnije središte intelektualne i kulturne djelatnosti općenito. Ni Prvi svjetski rat nije zaustavio razvojne trendove. ${ }^{67}$ Težački Split koji se razvija i modernizira, čiji društveni život postaje slojevitiji, nalazimo kod književnika-kroničara grada, primjerice Marka Uvodića i Ivana

63 HR-HDA, Služba državne sigurnosti republičkog sekretarijata za unutrašnje poslove SRH, Zapisnik sa saslušanja Kerubina Šegvića, 001.16

64 Bogdan Radica, Živjeti nedoživjeti, knj. 2: Uspomene hrvatskog intelektualca kroz apokalipsu Jugoslavije, München - Barcelona 1984., 337-338. Informaciju o Rittigu koju Radica prenosi potvrđuje i Nada Kisić-Kolanović u analizi „velikih sudskih procesa“ u Hrvatskoj od 1945. do 1948., također ističući napore Svetozara Rittiga u posredovanja između države i katoličkog klera. Nada Kisıć-Kolanović, „Vrijeme političke represije: 'veliki sudski procesi' u Hrvatskoj 1945.-1948.“, Časopis za suvremenu povijest, 25/1993., br. 1, 4-5.

65 Preuzeto iz: Bleiburška tragedija hrvatskoga naroda (ur. Franjo Nevistić i Vilko Nikolić), München - Barcelona 1976., 373. Usp. „Prosvjedna predstavka Alojzija Stepinca“, Stopama pobijenih. Glasilo Vicepostulature postupka mučeništva "Fra Leo Petrović i 65 subraće“, 7/2014., br. 12, 25-31.

66 „Inspiratore i izvršioce nečuvenih zločina nad našim narodom i njihove pomagače stigla je zaslužena kazna“, Vjesnik (Zagreb), br. 61, 30. 6. 1945., 2.

67 Vidi: Aleksandar JAKIR, „O nekim značajkama razvoja Splita u međuratnom razdoblju“, Vladan Desnica i Split 1920. - 1945. Zbornik radova sa znanstvenog skupa Desničini susreti 2014. (ur. Drago Roksandić i Ivana Cvijović Javorina), Zagreb 2015., 13-25. 
Kovačića. Branko Radica u svojim esejima u knjizi Salona i Split ističe kroz kraći kronološki pregled pionire „kulturno-umjetničke renesanse“ Splita, korifeje poput kipara Ivana Rendića, Tome Rosandića, Branislava Deškovića i Ivana Meštrovića, slikara Vlahe Bukovca, Celestina Medovića, Emanuela Vidovića, Mirka Račkog i Vlahe Draganje te likovnih umjetnika-karikaturista Ante Katunarića i Virgila Meneghella Dinčića, potom književnika Tresića-Pavičića, Begovića, Katalinića-Jeretova, Marjanovića, skladatelja Josipa Hatzea, arhitekata Ante Bezića i Kamila Tončića, filmskog snimatelja Josipa Karamana i brojnih drugih koji oko 1900. djeluju u Splitu. ${ }^{68}$ Spomenuti su umjetnički i intelektualni predvodnici često jasan trag ostavljali na različitim područjima gradske kulture, svojim brojnim i višestranim aktivnostima. Iako često nisu ostajali dugotrajno vezani uz Split te su prelazili najčešće u Zagreb, ti su važni predstavnici kulturne i intelektualne elite grada, osim što su svojim djelovanjem ostali trajno povezani s gradom i Dalmacijom, ostavili dugoročno vrijedan trag. Iza njih su ostali listovi, časopisi, novine, krugovi, društva. Oko 1900. godine uspostavljaju se komunikacijski tokovi i dijaloški prostori, kritički intelektualno-kulturni krugovi koji, riječju Krune Prijatelja, djeluju sinkrono ${ }^{69}$ i unutar kojih se razvijaju različite generacije splitskih intelektualaca. One će tijekom međuratnog razdoblja, kao i vremena Drugog svjetskog rata i poslijeraća, uvelike obilježiti Split.

Kako objasniti taj uspon, koji se odvija usporedno $s$ velikim političkim promjenama i još važnije, pored Velikog rata 1914. - 1918. godine? Dakako, teorijski okvir koji se nalazi gotovo trenutno pri ruci je klasična uzročno-posljedična povezanost politike, ekonomije i kulture. Dakle, kulturni i intelektualni uspon potaknut promicanjem političkog statusa jednog grada i njegovim ekonomskim probitkom: takvo objašnjenje pronalazimo diljem urbane povijesti srednjoeuropskih ili mediteranskih gradova, od gotičkog Münchena i baroknog Beča, do Genove 13. ili Valencije 15. stoljeća. Isto bismo mogli zaključiti i u slučaju Splita: njegov uspon koincidira s uspostavom talijanske vlasti u Zadru nakon raspada Austro-Ugarske, kada Split postaje upravno središte Dalmacije. Međutim, povjesničarka Zdravka Jelaska Marijan upozorava na jednostranost takve interpretacije. Osim što je Split odabran za upravno središte u sklopu nove države 1918. još i prije talijanske okupacije Zadra, čime je izbor samo postao neminovan, Jelaska Marijan navodi važne trendove koji se već krajem 19. stoljeća uočavaju u razvoju Splita: od političkog života, društvene slojevitosti, razvoja obrazovnog sustava i modernizacije grada koja utječe na svakodnevicu, sve do gospodarskih čimbenika, razvoja splitske luke i prometnica. Jelaska Marijan također upozorava na položaj Rijeke i Trsta kao lučkih jadranskih gradova koji nakon Prvog svjetskog rata opadaju u odnosu na Split. ${ }^{70} \mathrm{Na}$ takvo razmišljanje nadovezuje se izjava Miljenka Smoje, koji će početak značajnih promjena u intelektualnom životu Splita smjestiti također oko 1900. godine, objašnjavajući da se u to vrijeme splitski studenti obrazuju izvan Dalmacije

$\overline{68}$ Branko Radica, Salona i Split. Epizode iz prošlosti, Split 1985., 237-243. O dinamici splitskog kulturnog života vidi između ostalih radova i: Ivana Tomić FERIć, „Glazbenička aktivnost Ante Katunarića u Splitu početkom 20. stoljeća“, Kulturna baština, 37/2011., 419-444; Duško KečKemet, Likovna umjetnost u Splitu 1900.-1941., Split 2011.

69 Kruno Prijatelj, „Likovna umjetnost u Dalmaciji u doba narodnog preporoda“, Hrvatski narodni preporod u Dalmaciji i Istri. Zbornik (ur. Jakša Ravlić), Zagreb 1969., 276-277.

70 Z. Jelaska Marijan, Grad i ljudi, 479-483. 
u Grazu, Beču ili Pragu, a po povratku u Split donose značajne novine - znanje i naročito sport - koji mijenjaju „ustaljeni ritam“ grada, „odnose [grad, odnosno ljude] u svit“ .71

Dakle, pred kraj 19. stoljeća modernizacijom i razvitkom grada stvaraju se uvjeti, od škola sve do kulturnih društava i javnih prostora komunikacija (naročito Hrvatski dom 1908.), koji će od Splita učiniti važno hrvatsko kulturno središte. Osim toga, obrazovani sloj književnika, umjetnika, arhitekata, arheologa i drugih stručnjaka, koji su školovani po različitim zapadnim i srednjoeuropskim središtima, aktivno sudjeluju s jedne strane kao prenositelji modernosti i modernih tendencija, a s druge strane naučeno znanje i stečena iskustva nastoje primijeniti na specifičan mediteransko-dalmatinski ambijent.

Pored tih „unutarnjih“ razvojnih faktora, koji su upravo od Splita učinili važno dalmatinsko središte, nameću se i „vanjski“ faktori koji utječu na kulturu i intelektualni život na prijelazu stoljeća. Nekoliko različitih historiografskih pristupa nude pomoć u rješenju ovog pitanja. Fernand Braudel je davno uočio, proučavajući povijest Mletačke Republike, kako političko opadanje jedne moćne države često izaziva svojevrsno preslagivanje snage $s$ politike na kulturu. ${ }^{72}$ Takvo shvaćanje je potom prilagođeno pitanju Habsburške Monarhije $s$ kraja 19. i početkom 20. stoljeća, što pokazuju između ostaloga Emil Brix ${ }^{73}$ i Ernst Hanisch. Hanisch dapače predlaže nekoliko mogućih rješenja u pitanju kako Beč postaje središte kulture i modernosti unutar politički oslabjelog imperija: od spomenute Braudelove teze do naglašavanja postojanja slojevitih, ali raznovrsnih društveno-kulturnih, multinacionalnih miljea is time povezane krize identiteta u Austro-Ugarskoj. ${ }^{74}$ Dodatni odgovor što ga okvir Habsburške Monarhije s kraja 19. stoljeća nudi, svakako je bijeg građanstva od izuzetno kompleksne, ali često inertne političke situacije, okretanje kulturi i umjetnosti kao prostoru izražavanja novih tendencija, modernosti i avangardnosti, nasuprot okoštalom političkom sustavu reprezentiranom u državnoj birokraciji. ${ }^{75}$ Teza na taj način pokriva ne samo Beč kao logično središte Monarhije, već i druge manje centre ili čak poluperiferiju, od očitih Praga i Budimpešte sve do Bratislave, Lavova, Zagreba itd. Taj se zaključak izuzetno dobro uklapa i u primjer Splita: Branko Radica uočit će da kulturni procvat i „kulminacija političke konfuzije" koincidiraju. ${ }^{76}$

Napravi li se odmak i od „habsburškog okvira“, nailazi se i na razmišljanja britanskih povjesničara formulirana oko tzv. efekta ili fenomena prijelaza stoljeća. Asa Briggs i Daniel Snowman, između ostalih, ističu kako simbolika prijelaza stoljeća/fin de siècle ima u dugoročnoj perspektivi snažan utisak na predvodnike razdoblja, jer unatoč činjenici da je kalendarsko vrijeme umjetna tvorevina, svijest o prijelazu, promjeni i novome tjera na

\footnotetext{
$\overline{71}$ Iz intervjua Selme Katunarić s Miljenkom Smojom (www.youtube.com/watch?v=TuPqo6ym9xo).

72 Fernand Braudel, Sredozemlje i sredozemni svijet u doba Filipa II., sv. 1, Zagreb 1997., 425. Vidi i druga Braudelova djela o Veneciji i Mediteranu.

73 Emil Brix, „The Role of Culture in the Decline of European Empires“, The Decline of Empires (ur. Emil Brix i dr.), München 2001., 9-20.

74 Ernst Hanisch, Der lange Schatten des Staates. Österreichische Gesellschaftsgeschichte im 20. Jahrhundert, Wien 2005., 247-251.

75 Isto, 250.

76 B. Radica, Salona i Split, 234-237.
} 
premišljanja o prošlosti, sadašnjosti i budućnosti, nudi čitav niz retrospektivnih, introspektivnih i autoanalitičkih preispitivanja koja utječu na mentalitet vremena. ${ }^{77}$

Zaokružujući navedene teze i teorije o kulturnom procvatu gradova Habsburške Monarhije s kraja 19. stoljeća nameće se ponovno jedna brodelijanska perspektiva, u ovom slučaju usmjerena na kulturnu povijest gradova u najširem smislu, uključujući intelektualni život, mreže komunikacija, krugove utjecaja. Ta perspektiva upozorava prije svega na prostorne aspekte, povezujući u jednom mahu Split s ostalim dalmatinskim ,središtima“, primjerice Zadrom i Dubrovnikom, ali i šire, $s$ dijelovima Monarhije, naročito Bečom i Pragom te Italijom, ali i Srbijom i Crnom Gorom - kao mediteranskim i srednjoeuropskim prostorom formiranja i artikuliranja intelektualnih krugova. Ona međutim ukazuje i

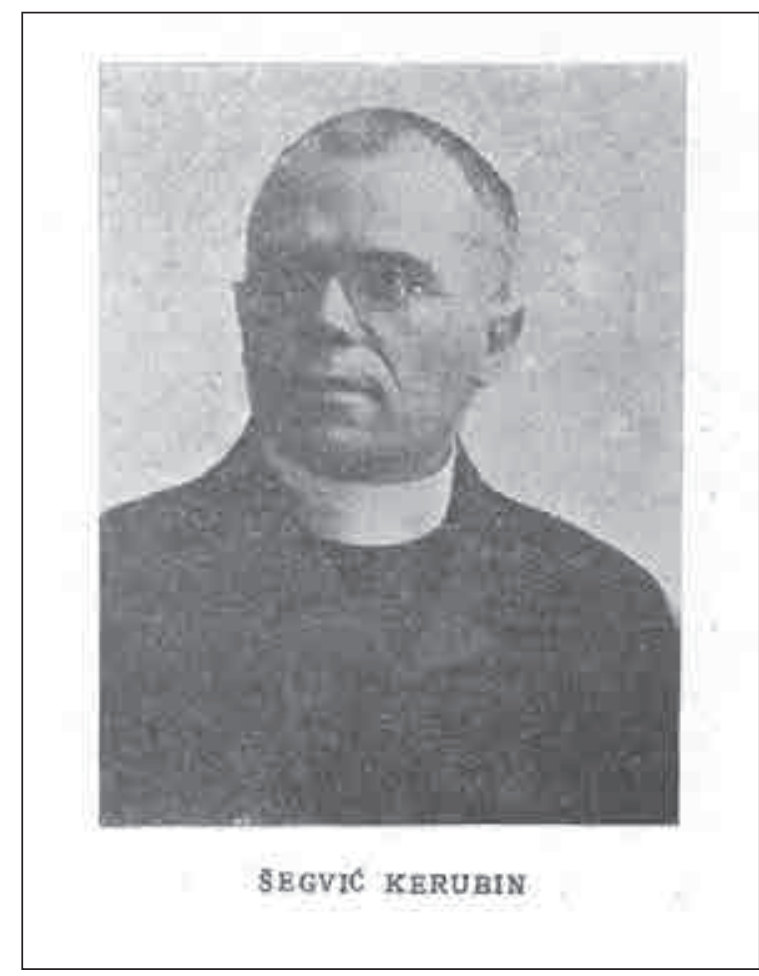

Sl. 7. Fotografija Kerubina Šegvića objavljena u publikaciji Znameniti i zaslužni Hrvati (Zagreb, 1925.) na dugoročne procese i mentalitete na koje političke promjene doduše utječu, ali ne predstavljaju nužno prekretnice. Razdoblje oko 1900. i međuratni period, unatoč bitnim političkim i gospodarskim lomovima, povezano je upravo nastavkom kulturno-umjetničke i intelektualne dinamike uspostavljene u habsburškom periodu: na primjerima Beča, Praga, ali vrlo očito i Zagreba i Splita uočavaju se razvojni obrasci, odnos prema modernizaciji i modernom, mentaliteti i okviri djelovanja koji nameću vlastiti vremenski kontinuitet. Hrvatski intelektualci, koji su nakon 1918. godine u političkom smislu konfrontirani s različitim novim kategorijama i problemskim kompleksima, često pritom primjenjuju rješenja, pristupe, principe i zaključke koje vuku iz svojeg formativnog razdoblja, iz prijašnjih iskustava i načina djelovanja ili razmišljanja. Na taj se način, uz očito skrivene kontinuitete, otkrivaju i kojekakve logičke nedosljednosti, obilježavajući dodatno te intelektualce i gradove u kojima djeluju i koji su ih formirali. Split se kao urbani dalmatinski prostor pokazao kao jedno od takvih središta, koje u kontinuitetu raste i napreduje, razvija svoje intelektualne mreže od razdoblja pred kraj 19. stoljeća pa sve do i tijekom međuratnog perioda.

To je kontekst unutar kojega i Kerubin Šegvić djeluje u Splitu, ali i izvan Splita. On obrazovanje stječe na različitima mjestima (Zadar, Zagreb, Beč), djeluje diljem istočnog

77 Asa Briggs - Daniel Snowman, Fins de Siècle. How Centuries End 1400-2000, New Haven - London 1996. Vidi također: Mikuláš TeICH - Roy Porter, Fin de Siècle and Its Legacy, Cambridge 1993. 
Jadrana (Zadar, Trst, Kotor, Dubrovnik, Šolta, itd.) i šire (Sarajevo, Zagreb). Kao osoba klasične naobrazbe, bečki student arheologije i štovatelj odnosno poznavatelj talijanske kulture, Šegvić će u dinamiku Splita oko 1900. i međuratnog grada unositi i sudjelovati u brojnim svakidašnjim temama kulturnog života grada. Na njega utječu klerikalni pravaški mislioci 19. stoljeća koji su povezivali politiku i kulturu, shvaćali znanost i umjetnost kao još jedan od modusa prenošenja legitimacijskih političkih poruka, programa i ideologija. Šegvić će se tijekom svojeg djelovanja kao povjesničar, arheolog, novinar, političar i književnik često vraćati u Split, ponekad dulje, ponekad tek u prolazu. On će, unatoč tome što u posljednjim desetljećima života djeluje gotovo isključivo u Zagrebu, kao i brojni drugi predstavnici intelektualnog života Splita, biti trajno prisutan, kako u diskursu vremena, tako i u općenitom kulturnom razvoju.

\section{$\cos$}

\section{The City as a Place of Formation of the Intellectual: Kerubin ŠEgVić and Split}

In the richly nuanced cultural and intellectual circles in interwar Split one can discern a connection with the legacy of the fallen Austro-Hungarian Monarchy. In spite of the political rise of Split as the new administrative centre of Dalmatia after 1918, there is a continuity with the turn of the century period noticeable precisely in intellectual life. Kerubin Šegvić belongs to those persons in Split scientific, political and public life whose work sought to tie together the political, intellectual and cultural spheres, opening and even creating controversial problems. As a public person, Šegvić was active in different circles in Split, as a close collaborator of don Frane Bulić, as a prominent member of the Croatian Party of Rights, and as a writer, newspaper critic, and later editor. At the same time, he was often a target of criticism, and sometimes mockery in his native Split, and many prominent intellectuals engaged in fierce scientific and political polemics with him (Fran Galović, Antun Gustav Matoš, Miroslav Krleža, August Cesarec, etc.). This intellectual and historical portrait reveals different segments of Šegvićs's ideologies in his political and scientific statements, and especially the changes that marked him from his early association with the Croatian Party of Rights in the 1890s to his losing his life in 1945.

Key words: Kerubin Šegvić, intellectual, Split, city, polemics, criticism

\section{$\cos$}

\section{Izvori i literatura}

\section{Neobjavljeni izvori}

Hrvatski državni arhiv (Zagreb)

HR-HDA, Služba državne sigurnosti republičkog sekretarijata za unutrašnje poslove SRH, Zapisnik sa saslušanja Kerubina Šegvića, 001.16

Državni arhiv u Zagrebu (Zagreb) 
DAZG 849, osobni fond Ivan Peršić, „Fanatici i realisti, kompromisanti i ekstremisti u hrvatskoj politici najsudbonosnijih trideset godina od 1914/15 do 1944/45“, kutija 1.

Nacionalna i sveučilišna knjižnica (Zagreb)

NSK, R-7982, B-b, 5-6, Pismo Krunoslava Bege Kerubinu Šegviću od 31. 12. 1931.

NSK, R-7982, B-b, 51-57, Iz pisma Vinka Lozovine Kerubinu Šegviću od 19. 9. 1940.

NSK, R-7982, B-b, 113, pismo Ive Tartaglije Kerubinu Šegviću od 11. 4. 1927.

\section{Objavljeni izvori}

Agramer Zeitung (Zagreb), 1909. - 1910.

Duje Balavac (Split), 1911.

Glas Matice hrvatske (Zagreb), 1907., 1909.

Hrvatska (Zagreb), 1907.

Hrvatski borac (Zagreb), 1922.

Hrvatska država (Zagreb), 1918.

Hrvatsko kolo (Zagreb), 1908.

Hrvatski list (Osijek), 1926. - 1927.

Hrvatska obzorja (Split), 1996.

Hrvatska smotra (Zagreb), 1934., 1936. - 1937.

Hrvatska straža (Zagreb), 1939.

Javnost (Beograd), 1936.

Mladost (Zagreb), 1925.

Solinska kronika (Solin), 2010.

Večernji list (Zagreb), 1969.

Vjesnik (Zagreb), 1945.

Cherubin ŠEgvić, „Chronologie des Évęques de Salone suivie de la Chronologie des Archevêques de Spalato“, Analecta Bollandiana, sv. 33, 1914., 265-274.

Cherubin ŠEgvić, Na solinskih rusevinah. Pripoviest iz staro-kršćanske dobe u Solinu, Zagreb [s.a.].

Cherubin ŠEgvić, „Život i djela Evgenija Kumičića“, u: Eugen Kumičić, Jelkin bosiljak. Pripoviest iz istarskoga života, Zagreb 1905.

Cherubino ŠEgvić, „Iscrizione sepolcrale di Elena, figlia di Tomislavo, regina croata“, Supplemento al 'Bullettino di archeologia e storia dalmata', 1902., br. 4-5, 1-21.

Kerubin ŠEGVIĆ, Gramatika talijanskog jezika u dvadeset i pet lekcija sa praktičnim dodatkom, Zagreb [1927.]; drugo izdanje: Zagreb 1941.

Kerubin ŠEgvić, Luka Botić. Njegov život i njegova djela, Zagreb 1930.

K[erubin] Š[EGVIĆ], Talijansko trgovačko dopisivanje - Corrispondenza commerciale italiana, Zagreb [s.a.].

Kerubin ŠEgvić, Toma Splićanin. Državnik i pisac 1200.-1268., Zagreb 1927.

Kerubin ŠEgvić, Vjera Vidova ili religija Srba i Hrvata, Split 1899.

Kerubin ŠEgvić, Vodič kroz Rim i okolicu, Zagreb 1925.

Mitteilungen der K.K. Zentral-Kommission für Erforschung und Erhaltung Kunst- und Historischen Denkmale, Wien 1904. 
Stenografske beleške Privremenog narodnog predstavništva Srba, Hrvata i Slovenaca: 14. redovni sastanak, Zagreb 1919.

\section{Literatura}

Tomislav BRAnĐolicA, „Društvena raslojavanja u međuratnom Splitu: jedna povijest odozdo“, Vladan Desnica i Split 1920. - 1945. Zbornik radova sa znanstvenog skupa Desničini susreti 2014. (ur. Drago Roksandić i Ivana Cvijović Javorina), Zagreb 2015., 27-40.

Fernand Braudel, Sredozemlje i sredozemni svijet u doba Filipa II., sv. 1, Zagreb 1997.

Asa Briggs - Daniel Snowman, Fins de Siècle. How Centuries End 1400-2000, New Haven London 1996.

Emil Brix, „The Role of Culture in the Decline of European Empires“, The Decline of Empires (ur. Emil Brix i dr.), München 2001., 9-20.

Frane Bulić, Izabrani spisi, Split 1984.

André Burguière, The Annales School. An Intellectual History, Ithaca - London 2009.

Stefan Collini, Absent Minds. Intellectuals in Britain, Oxford 2006.

Josip Dukić, „Istraživanje i objavljivanje salonitanskih kršćanskih natpisa“, Tusculum, 2/2009., br. 2, 173-204.

Stjepan GunjaČA, Ispravci i dopune starijoj hrvatskoj historiji, sv. 1: Izvori, Zagreb 1973.

Ernst Hanisch, Der lange Schatten des Staates. Österreichische Gesellschaftsgeschichte im 20. Jahrbundert, Wien 2005.

Iskra Iveljıć, Očevi i sinovi. Privredna elita Zagreba u drugoj polovici 19. stoljeća, Zagreb 2007.

Aleksandar JAKIR, „O nekim značajkama razvoja Splita u međuratnom razdoblju“, Vladan Desnica i Split 1920. - 1945. Zbornik radova sa znanstvenog skupa Desničini susreti 2014. (ur. Drago Roksandić i Ivana Cvijović Javorina), Zagreb 2015., 13-25.

Zdravka Jelaska Marijan, Grad i ljudi: Split 1918.-1941., Zagreb 2009.

Duško KečKemet, Likovna umjetnost u Splitu 1900.-1941., Split 2011.

Nada Kisıć-Kolanović, „Vrijeme političke represije: 'veliki sudski procesi' u Hrvatskoj 1945.1948.“, Časopis za suvremenu povijest, 25/1993., br. 1, 1-23.

Zvonko Kovač, „Tumačenje i prikazivanje intelektualaca-umjetnika danas“, Intelektualac danas. Zbornik radova s mecunarodnog skupa Desničini susreti 2013. (ur. Drago Roksandić i Ivana Cvijović Javorina), Zagreb 2014., 107-121.

Ivan Kovačıć, Smij i suze starega Splita, Pennsylvania 1970.

Friedrich Lenger - Klaus Tenfelde (ur.), Die europäische Stadt im 20. Jahrhundert. Wahrnehmung - Entwicklung - Erosion, Köln - Weimar - Wien 2006.

Saša Luubičıć, „Bettize nisu napustili Split zbog partizana“, Slobodna Dalmacija (Split), 24.11. 2004. (http://arhiv.slobodnadalmacija.hr/20041124/temedana01.asp).

F. W. Maitland, Township and Borough, Cambridge 1898.

Vesna Miović - Nikša Selmani, „Turska kancelarija i Acta Turcarum od vremena Dubrovačke Republike do danas“, Anali Dubrovnik, 45/2007., 235-284.

Hrvoje Morović, Povijest biblioteka u gradu Splitu, sv. 1, Zagreb 1971.

Krešimir Nemec, Čitanje grada. Urbano iskustvo u hrvatskoj književnosti, Zagreb 2010.

Franjo Nevistić - Vilko Nikolić (ur.), Bleiburška tragedija hrvatskoga naroda, München - Barcelona 1976. 
Božidar Petrač, „Svestranost i neujednačenost opusa Kerubina Šegvića“, u: Kerubin ŠEgvić, Aporije književnosti i povijesti, Zagreb 2013., 7-92.

Kruno Prijatelj, „Likovna umjetnost u Dalmaciji u doba narodnog preporoda“, Hrvatski narodni preporod u Dalmaciji i Istri. Zbornik (ur. Jakša Ravlić), Zagreb 1969., 472-485.

„Prosvjedna predstavka Alojzija Stepinca“, Stopama pobijenih. Glasilo Vicepostulature postupka mučeništva „Fra Leo Petrović i 65 subraće“, 7/2014., br. 12, 25-31.

Bogdan RadicA, Hrvatska 1945, München - Barcelona 1974.

Bogdan Radica, Sredozemni povratak, München - Barcelona 1971.

Bogdan Radica, Živjeti nedoživjeti, knj. 1: Uspomene hrvatskog intelektualca kroz moralnu i ideološku krizu Zapada, München - Barcelona 1982.

Bogdan RadicA, Živjeti nedoživjeti, knj. 2: Uspomene hrvatskog intelektualca kroz apokalipsu Jugoslavije, München - Barcelona 1984.

Branko Radica, Salona i Split. Epizode iz prošlosti, Split 1985.

Nikola Rušınović, Moja sjećanja na Hrvatsku, Zagreb 1996.

Mikuláš Teich - Roy Porter, Fin de Siècle and Its Legacy, Cambridge 1993.

Ivana Tomić Ferić, „Glazbenička aktivnost Ante Katunarića u Splitu početkom 20. stoljeća“, Kulturna baština, 37/2011., 419-444.

Znameniti i zaslužni Hrvati te pomena vrijedna lica u hrvatskoj povijesti od 925-1925., Zagreb 1925.

\section{Televizijski intervju}

Intervju Selme Katunarić s Miljenkom Smojom (www.youtube.com/watch?v=TuPqo6ym9xo). 